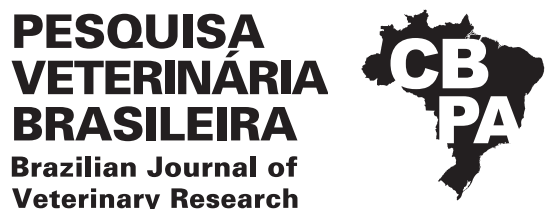

Pesq. Vet. Bras. 41:e06747, 2021

DOI: 10.1590/1678-5150-PVB-6747

Original Article

Livestock Diseases

ISSN 0100-736X (Print)

ISSN 1678-5150 (Online)

\title{
Stx 1 and Stx 2 subtyping and antimicrobial resistance in Shiga toxin-producing Escherichia coli (STEC) isolates from cattle and sheep feces in the Southeastern region of the State of Goiás, Brazil ${ }^{1}$
}

\author{
Bruna R. Arrais ${ }^{2}$, Ângela V.B.A. Silveira ${ }^{2}$, Angélica F. Oliveira ${ }^{2}$, Nayara C. Barbosa ${ }^{2}$, \\ Ariel E. Stella ${ }^{2}$ (D), Benner G. Alves ${ }^{2}$ (D), Marcos R.A. Ferreira ${ }^{3 *}$ (D) \\ and Cecília N. Moreira ${ }^{2}$
}

\begin{abstract}
Arrais B.R., Silveira A.V.B.A., Oliveira A.F., Barbosa N.C., Stella A.E., Alves B.G., Ferreira M.R.A. \& Moreira C.N. 2021. Stx1 and Stx2 subtyping and antimicrobial resistance in Shiga toxin-producing Escherichia coli (STEC) isolates from cattle and sheep feces in the Southeastern region of the State of Goiás, Brazil. Pesquisa Veterinária Brasileira 41:e06747, 2021. Graduate Program in Animal Bioscience, Universidade Federal de Jataí, Campus Jatobá, BR-364 Km 195 3800, Cidade Universitária, Jataí, GO 75801-615, Brazil. E-mail: marcosferreiravet@gmail.com

The present study was aimed at subtyping of Stx 1 and Stx2 genes and characterization of antimicrobial resistance in 106 Shiga toxin-producing Escherichia coli (STEC) strains isolated from cattle and sheep feces. PCR was used to determine the subtypes, and the disk-diffusion method was used to evaluate the antimicrobial resistance. Ten antibiotics from five different classes were tested. Among the isolates of bovine origin, two subtypes of Stx1 (Stx1a and Stx1c), and four subtypes of Stx2 (Stx2a, Stx2b, Stx2c, and Stx2d) were identified. In isolates of sheep origin, two subtypes of Stx1 (Stx1a and Stx1c), and four subtypes of Stx2 (Stx2a, $S t \times 2 b, S t \times 2 c$, and $S t \times 2 g$ ) were identified. The results obtained suggest the presence of high diversity in Stx1 and Stx2 genes. Further, 96.6\% (57/59) of bovine fecal strains and 89.4\% $(42 / 47)$ of sheep fecal strains showed resistance to at least one tested antibiotic. In both animal species, most strains were multidrug-resistant (MDR) $(67.8 \%$ in cattle and $59.6 \%$ in sheep), with no significant difference between host animals. Adult animals were eight times more likely to have STEC with greater pathogenic potential. STEC with the highest pathogenic potential were three times more likely to be multidrug-resistant than STEC with the lowest pathogenic potential. The data reported in this study suggests the occurrence of strains with high potential pathogenicity in the region studied. Therefore, the ruminants of this region are carriers of strains that can cause infections in humans.
\end{abstract}

INDEX TERMS: Stx1, Stx2, subtyping, antimicrobial resistance, Shiga toxin, Escherichia coli, STEC, cattle, sheep, feces, Brazil, ruminants, public health, food security, multidrug-resistant, virulence factors.

RESUMO.- [Subtipagem de $\operatorname{Stx} 1$ e $S t x 2$ e resistência antimicrobiana em isolados de Escherichia coli produtoras de toxina Shiga (STEC) de fezes de bovinos e ovinos na região sudeste de Goiás, Brasil.] 0 presente estudo teve

\footnotetext{
${ }^{1}$ Received on February 9, 2021.

Accepted for publication on March 18, 2021.

${ }^{2}$ Graduate Program in Animal Bioscience, Universidade Federal de Jataí (UFJ), Campus Jatobá, BR-364 Km 195 3800, Cidade Universitária, Jataí, GO 75801-615, Brazil.

${ }^{3}$ Centro de Desenvolvimento Tecnológico, Biotecnologia, Universidade Federal de Pelotas (UFPel), Rua Gomes Carneiro 1, Centro, Pelotas, RS 96010-610, Brazil. *Corresponding author: marcosferreiravet@gmail.com
}

como objetivo subtipar os genes Stx1 e Stx2 e caracterizar a resistência antimicrobiana em 106 isolados de Escherichia coli produtoras de toxinas Shiga (STEC) isoladas de fezes de bovinos e ovinos. A PCR foi utilizada para determinar os subtipos e o método de difusão em disco foi utilizado para avaliar a resistência antimicrobiana. Dez antibióticos de cinco classes diferentes foram testados. Entre os isolados de origem bovina, foram identificados dois subtipos de Stx 1 (Stx1a e Stx1c) e quatro subtipos de Stx2 (Stx2a, Stx2b, Stx2c e $S t x 2 d$ ). Nos isolados de origem ovina, foram identificados dois subtipos de Stx1 (Stx1a e Stx1c) e quatro subtipos de Stx2 (Stx2a, Stx2b, Stx2c e Stx2g). Os resultados obtidos sugerem 
a presença de alta variabilidade nos genes $S t x 1$ e Stx2. Além disso, 96,6\% (57/59) dos isolados fecais de bovinos e 89,4\% (42/47) dos isolados de ovinos mostraram resistência a pelo menos um antibiótico testado. Em ambas as espécies animais, a maioria das cepas foi multirresistente (MDR) $(67,8 \% \mathrm{em}$ bovinos e 59,6\% em ovinos), sem diferença significativa entre as espécies animais do reservatório. Os animais adultos tiveram oito vezes mais chances de apresentar STEC com maior potencial patogênico. STEC com o maior potencial patogênico teve três vezes mais chances de ser multirresistente do que o STEC com o menor potencial patogênico. Os dados relatados neste estudo sugerem a ocorrência de cepas com alto potencial de patogenicidade na região estudada. Portanto, os ruminantes dessa região são hospedeiros de isolados que podem causar infecções em humanos.

TERMOS DE INDEXAÇÃO: Subtipagem, Stx1, Stx2, resistência antimicrobiana, Escherichia coli, toxina Shiga, STEC, fezes, bovinos, ovinos, Brasil, ruminantes, saúde pública, segurança alimentar, mutidroga resitentes, fatores de virulência.

\section{INTRODUCTION}

Shiga toxin-producing Escherichia coli (STEC) strains are associated with serious infections in humans, such as hemolytic uremic syndrome (HUS), hemorrhagic colitis, meningitis, and septicemia (Karmali et al. 2010). They pose a serious public health threat, as they are frequently associated with severe illness and outbreaks in humans, which are transmitted from animals (Veneti et al. 2019). STEC is a diverse group of bacteria characterized by the production of potent cytotoxins, called Shiga toxin 1 and Shiga toxin 2 (Stx1 and Stx2), which bind to the same receptor and act on the same target in the cell but differ in the level of cytotoxicity (Russo et al. 2014, Cherubin et al. 2019). Ruminants, especially cattle and sheep, are the main reservoirs of STEC, shedding these bacteria in the feces, which get directly or indirectly transmitted to humans, thereby causing diseases (Ferreira et al. 2014, Yang et al. 2017).

There are three subtypes of Stx 1 (Stx $1 a$, Stx $1 c$, and Stx $1 d$ ) and seven of Stx2 (Stx2a,Stx2b,Stx2c,Stx2d,Stx2e,Stx2f, and $S t \times 2 g$ ). The simultaneous expression of more than one subtype can increase the in-vivo toxicity of the non-0157 strain, making it as virulent as the 0157: H7 strain (Scheutz et al. 2012, Jajarmi et al. 2017). Stx1a is more cytotoxic to Vero cells than Stx $2 a$, but Stx $2 a$ has a lower $50 \%$ lethal dose $\left(\mathrm{LD}_{50}\right)$ in mice (Russo et al. 2014, Cherubin et al. 2019). Epidemiological data suggest that infections with STEC isolates that produce only Stx $2 a$, progress more frequently to HUS than isolates that produce only Stx1a or produce both Stx1a and Stx2a (Petro et al. 2019).

STEC strain has shown markedly high resistance to antimicrobials. The development of multidrug-resistant (MDR) strains contributes to the increase of emerging pathogens and facilitates the movement of mobile genetic elements of drug resistance, leading to the spread of antibiotic resistance to other bacteria (Gentle et al. 2020, Yang et al. 2020). The objective of the present study was to identify the subtypes in 106 STEC strains isolated from cattle and sheep feces, to determine the susceptibility of these subtypes to antimicrobials, and to characterize them based on age, species, and sex of the animals.

\section{MATERIALS AND METHODS}

One hundred and six isolates STEC were selected from the collection of isolates of the "Laboratório de Microbiologia Veterinária" of the "Universidade Federal de Jataí" (UFJ). These were isolated from Girolando cattle $(n=59)$ and healthy Santa Inês sheep $(n=47)$ in studies carried out in the southwest region of the state of Goiás, Brazil (Ferreira et al. 2014, 2015). The isolates were selected according to age (young or adult), sex (males or females), and subtypes, i.e., Stx1 or Stx2 (Table 1).

For subtyping, the methodology and all the primers described by Scheutz et al. (2012) were used with adaptations. Triplex PCR for Stx1 subtyping was performed in $25 \mu \mathrm{L}$ reaction mixture containing $5 \mu \mathrm{L}$ of the bacterial DNA, $1 \times$ PCR buffer (Sinapse Biotecnologia, Brazil), $3 \mathrm{mM} \mathrm{MgCl}$ (Sinapse Biotecnologia, Brazil), $0.4 \mathrm{mM}$ of dNTPs (Sinapse Biotecnologia, Brazil), 1U of Taq DNA polymerase (Sinapse Biotecnologia, Brazil), $0.2 \mu \mathrm{M}$ of each of the Stx1c and Stx $1 d$ primer pairs (Sigma-Aldrich, United States), and $0.4 \mu \mathrm{M}$ of Stx $1 a$ primer pair (Sigma-Aldrich, United States). The reactions for subtyping of Stx2 samples were carried out in $20 \mu \mathrm{L}$ mixture containing $5 \mu \mathrm{L}$ of the bacterial DNA, $1 \times$ PCR buffer (Sinapse Biotecnologia, Brazil), $3 \mathrm{mM} \mathrm{MgCl}_{2}$ (Sinapse Biotecnologia, Brazil), $0.4 \mathrm{mM}$ dNTP (Sinapse Biotecnologia, Brazil), 1U of Taq DNA polymerase (Sinapse Biotecnologia, Brazil), and $0.3 \mu \mathrm{M}$ of each primer pair.

All reactions were performed in a thermocycler (Veriti Thermal Cicler, Applied Biosystems, United States) programmed for initial denaturation at $95^{\circ} \mathrm{C}(15 \mathrm{~min})$, followed by 35 cycles at $94^{\circ} \mathrm{C}(50$ s), $64^{\circ} \mathrm{C}(40 \mathrm{~s}), 72^{\circ} \mathrm{C}(1 \mathrm{~min})$, and a final extension at $72^{\circ} \mathrm{C}(3 \mathrm{~min})$, except for those using Stx $2 d$ primers, when the annealing temperature was adjusted to $66^{\circ} \mathrm{C}$. The amplified products were detected by $2 \%$ agarose gel electrophoresis (BioAmerica Biotech ${ }^{\circledR}$ ). Electrophoretic separation was performed at $80 \mathrm{~V}$ for $2.5 \mathrm{~h}$.

Antibiotic sensitivity tests were performed using the disk diffusion method according to the Clinical \& Laboratory Standards Institute,

Table 1. Primers used to determine the subtypes of Stx1 and $S t x 2$

\begin{tabular}{|c|c|c|}
\hline Primers & Sequences (5'-3') & Amplicon (bp) \\
\hline stx1a-F1 & CCTTTCCAGGTACAACAGCGGTT & 478 \\
\hline stx1a-R2 & GGAAACTCATCAGATGCCATTCTGG & \\
\hline stx $1 c-\mathrm{F} 1$ & ССTTTCCTGGTACAACTGCGGTT & 252 \\
\hline stx $1 c-\mathrm{R} 1$ & CAAGTGTTGTACGAAATCCCCTCTGA & \\
\hline stx $1 d-\mathrm{F} 1$ & CAGTTAATGCGATTGCTAAGGAGTTTACC & 203 \\
\hline stx1d-R2 & СTCTTCCTCTGGTTCTAACCCCATGATA & \\
\hline stx2a-F2 & GCGATACTGRGBACTGTGGCC* & 349 \\
\hline stx2a-R3 & CCGKCAACCTTCACTGTAAATGTG* & \\
\hline$s t \times 2 b-\mathrm{F} 1$ & AAATATGAAGAAGATATTTGTAGCGGC & 251 \\
\hline$s t \times 2 b-\mathrm{R} 1$ & CAGCAAATCCTGAACCTGACG & \\
\hline$s t \times 2 c-\mathrm{F} 1$ & GAAAGTCACAGTTTTTATATACAACGGGTA & 177 \\
\hline stx $2 c-\mathrm{R} 2$ & CCGGCCACYTTTACTGTGAATGTA & \\
\hline$s t \times 2 d-\mathrm{F} 1$ & AAARTCACAGTCTTTATATACAACGGGTG & 280 \\
\hline stx2d-R1 & GCCTGATGCACAGGTACTGGAC & \\
\hline stx $2 e-\mathrm{F} 1$ & CGGAGTATCGGGGAGAGGC & 411 \\
\hline stx2e-R2 & CTTCCTGACACCTTCACAGTAAAGGT & \\
\hline stx2f-F1 & TGGGCGTCATTCACTGGTTG & 424 \\
\hline stx2f-R1 & TAATGGCCGCCCTGTCTCC & \\
\hline$s t \times 2 g-\mathrm{F} 1$ & CACCGGGTAGTTATATTTCTGTGGATATC & 573 \\
\hline stx2g-R1 & GATGGCAATTCAGAATAACCGCT & \\
\hline
\end{tabular}

${ }^{*}$ Degenerate primers that were synthesized according to Scheutz et al. (2012). 
with modifications (CLSI 2018). Ten antimicrobials of five classes were

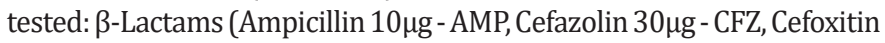
$30 \mu \mathrm{g}$ - CFO, Cefotaxime 30 $\mathrm{g}$ - CTX, Cefepime 30 $\mathrm{g}$ - CPM, Imipenem

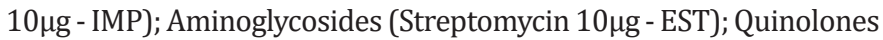

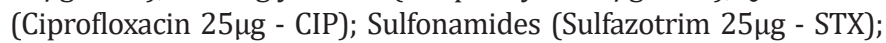

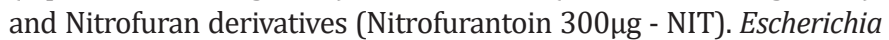
coli ATCC 25922 was used as a control strain (CLSI 2018). The isolates that had resistance to two or more different classes of antibiotics were considered MDR-isolates, according to Shaheen et al. (2010).

All statistical analyses were performed using the Sigma Plot version 11 program (Systat Software Inc., USA). The proportionate data were compared using the chi-square test. The logistic regression analysis evaluated the influence of age (young or adult), sex (male or female), species (bovine or sheep), and resistance (non-resistant or multi-resistant) as independent variables. The subtype presented was STEC with less pathogenic potential, i.e., subtypes of Stx1; and STEC with greater pathogenic potential, i.e., subtypes of Stx2 or subtypes of both Stx 1 and Stx2 (dependent variable). The generated data show the number of positive isolates for the Stx subtypes and were considered significant when $P<0.05$. The positives isolates are presented descriptively.

\section{RESULTS}

STEC subtype frequencies in bovine and ovine feces are given in Table 2. In cattle, the Stx $1 a+S t x 1 c$ subtypes (63.16\%) was found to be predominant over the Stx1a subtype single (36.84\%). Stx1c subtype single and the Stx1a+Stx1d and $S t x 1 c+S t x 1 d$ were not found. Among the Stx2 profile, the Stx $2 a+S t x 2 c$ subtype (57.57\%) predominated, followed by Stx2a+Stx2c+Stx2d subtype (15.15\%) and the Stx2c profile (15.15\%). The subtypes Stx2e and Stx2f were not found. In sheep, the Stx $1 a+$ Stx $1 c$ subtypes (56.09\%) was the most frequent, followed by the subtypes Stx1c (29.26\%) and Stx1a $(14.64 \%)$. The Stx1d subtype and the associations of Stx1a+ Stx $1 d$ and $S t x 1 c+S t x 1 d$ were not found. As for Stx2, the subtype Stx $2 b(73.91 \%)$ predominated, followed by associations of subtypes Stx $2 b+\operatorname{Stx} 2 g(21.73 \%)$ and $S t x 2 a+\operatorname{Stx} 2 c(4.34 \%)$. The subtypes $S t x 2 e$ and $S t x 2 f$ were not found (Fig.1-7).

Age and antimicrobial resistance were factors $(P<0.05)$ associated with isolates with greater pathogenic potential (Table 3 and 4). Adult animals were eight times more likely to have STEC with greater pathogenic potential, that is, to have Stx2 subtypes or Stx1 + Stx2, compared to young animals. STEC strains with the greatest pathogenic potential were three times more likely to be MDR as compared to those with the least pathogenic potential.

Only $3.4 \%(2 / 59)$ of bovine strains were sensitive to all tested antimicrobials, whereas $96.6 \%$ (57/59) were resistant to at least one class of antibiotic. In sheep, $10.6 \%(5 / 47)$ were sensitive to all, and $89.4 \%$ (42/47) were resistant to at least one drug. In cattle $67.8 \%$ of all isolates examined were MDR, while $59.6 \%$ of sheep isolates were MDR, there was no significant difference between the proportion of isolates that were MDR when cattle and sheep were compared $(P>0.05)$. The frequency of resistant strains is shown in Table 5. The strains showed greater resistance to nitrofurantoin, followed by cefotaxime and imipenem. Besides, it is important to note that the isolates of both animal species showed resistance to different antibiotics of the 1st, $2 \mathrm{nd}$, 3rd, and 4 th generation of cephalosporins: cefazolin, cefoxitin, cefotaxime, and cefepime, respectively.

\section{DISCUSSION}

The subtypes Stx1a and Stx1c individually or simultaneously in the same cell were found in samples of cattle and sheep. Although they bind to the same receptor, Stx2a is more toxic in mice, while Stx1a is more cytotoxic in cell culture (Russo et al. 2014). Stx1a is ten times more cytotoxic to Vero cells than Stx2a; however, the reverse is seen in mice: Stx1a is 100 to 400 times less lethal than Stx $2 a$, even though the toxins exhibit equivalent enzymatic activities (Melton-Celsa 2014, Cherubin et al. 2019, Petro et al. 2019). According to Scheutz et al. (2012), the subtypes Stx1a and Stx2a are the most frequently associated with HUS in humans.

Table 2. Stx1 and Stx2 subtypes of STEC isolated from cattle and sheep feces

\begin{tabular}{|c|c|c|}
\hline Animal & Subtypes & $\%(\mathrm{NP} / \mathrm{N})$ \\
\hline \multirow{3}{*}{$\begin{array}{l}\text { Cattle } \\
(\text { Stx } 1=38 / \text { Stx } 2=33)\end{array}$} & Stx1a & $36.84(14 / 38)$ \\
\hline & Stx $1 a$, Stx $1 c$ & $63.16(24 / 38)$ \\
\hline & $\begin{array}{c}\text { Stx2a and Stx2c } \\
\text { Stx2a, Stx2c, and Stx2d } \\
\text { Stx2b, Stx2c, and Stx } 2 d \\
\text { Stx2c, and Stx2d } \\
\text { Stx2c }\end{array}$ & $\begin{array}{c}57.57(19 / 33) \\
15.15(5 / 33) \\
3.03(1 / 33) \\
9.09(3 / 33) \\
15.15(5 / 33)\end{array}$ \\
\hline \multirow{4}{*}{$\begin{array}{l}\text { Sheep } \\
(\text { Stx } 1=41 / \text { Stx } 2=23)\end{array}$} & Stx1a & $14.64(6 / 41)$ \\
\hline & Stx $1 c$ & $29.26(12 / 41)$ \\
\hline & Stx $1 a$, and Stx $1 c$ & $56.09(23 / 41)$ \\
\hline & $\begin{array}{c}\text { Stx } 2 b \\
\text { St } 2 a \text { and St } 2 c \\
\text { St } 2 \text { 2b and St } 22 g\end{array}$ & $\begin{array}{c}73.91(17 / 23) \\
4.34(1 / 23) \\
21.73(5 / 23)\end{array}$ \\
\hline
\end{tabular}
for Stx1 or Stx2 subtypes.

Table 3. Description of the analyzed samples of cattle and sheep feces

\begin{tabular}{|c|c|c|}
\hline STEC & Cattle (59) ${ }^{\mathrm{a}}$ & Sheep $(47)^{\mathrm{a}}$ \\
\hline Age & 16 adult/43 young & 21 adult/26 young \\
\hline Sex & 41 female/18 male & 25 female/22 male \\
\hline Stx 1 & $25^{\mathrm{b}}$ & $25^{\mathrm{b}}$ \\
\hline Stx 2 & $20^{c}$ & $3^{c}$ \\
\hline Stx 1 and $S t x 2$ & $14^{\mathrm{d}}$ & $19^{d}$ \\
\hline
\end{tabular}

Table 4. Logistic regression coefficients and the odds ratios for the factors associated with the pathogenic potential in cattle and sheep

\begin{tabular}{cccc}
\hline Factors & Coefficients & $P$-value & Odds ratio (CI 95\%) \\
\hline Age $^{\mathrm{a}}$ & 2.1139 & 0.0002 & 8.28 \\
& & & $(2.72-25.17)$ \\
Sex $^{\mathrm{b}}$ & 0.3916 & 0.3982 & 1.47 \\
& & & $(0.60-3.67)$ \\
Species $^{\mathrm{c}}$ & -0.7193 & 0.1247 & 0.48 \\
& & & $(0.19-1.22)$ \\
Resistance $^{\mathrm{d}}$ & 1.1585 & 0.0282 & 3.18 \\
& & & $(1.13-8.96)$
\end{tabular}

Intercept $\quad-1.3319$

$\overline{\mathrm{CI}}=$ Confidence interval; Dependent variable: pathogenic potential ( minor $=0$, ajor $=1) ;{ }^{\text {a }}$ age: young $=0$, adult $=1{ }^{b}$ sex: male $=0$, female $=1$; ${ }^{\mathrm{c}}$ species: bovine $=0$, sheep $=1 ;{ }^{\mathrm{d}}$ resistance: $\mathrm{NMDR}=0, \mathrm{MDR}=1$. 
Although the Stx1a subtype was detected in both the animal species, the association of Stx $1 a+$ Stx $1 c$ subtypes was the most frequent. Similar results were reported by Alonso et al. (2017). It is noteworthy that the simultaneity of subtypes is often found. In the study conducted by Taghadosi et al. (2018), two isolates from calves harbored five Stx subtypes. According to these authors, strains with a combination of Stx1+
Stx2 genes are more cytotoxic. In the present study, $23.7 \%$ $(14 / 59)$ and $40.4 \%$ (19/47) of the strains obtained from cattle and sheep, showed subtypes Stx1 and Stx2 simultaneously, being considered to have the greatest pathogenic potential.

The subtypes Stx $1 c$ and Stx $1 d$ are rarely associated with disease in humans, and when present in STEC, they are associated with mild disease. The low number of positive isolates for Stx $1 \mathrm{c}$ and

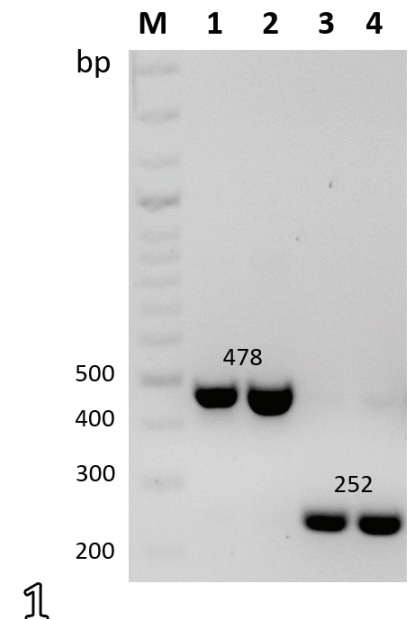

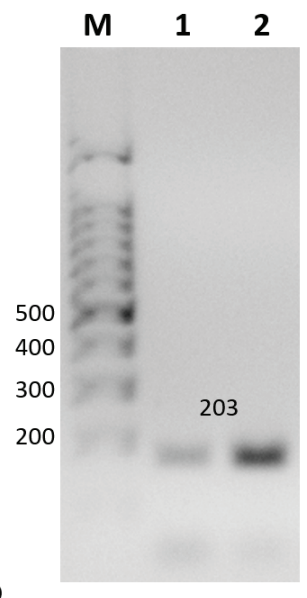

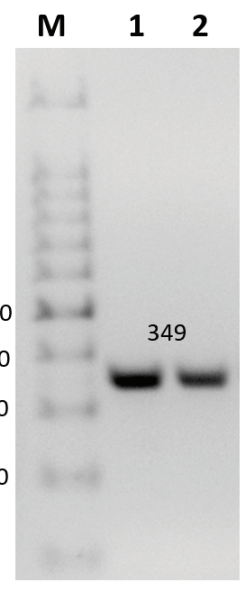

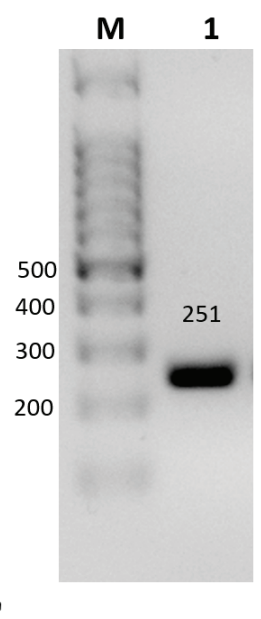
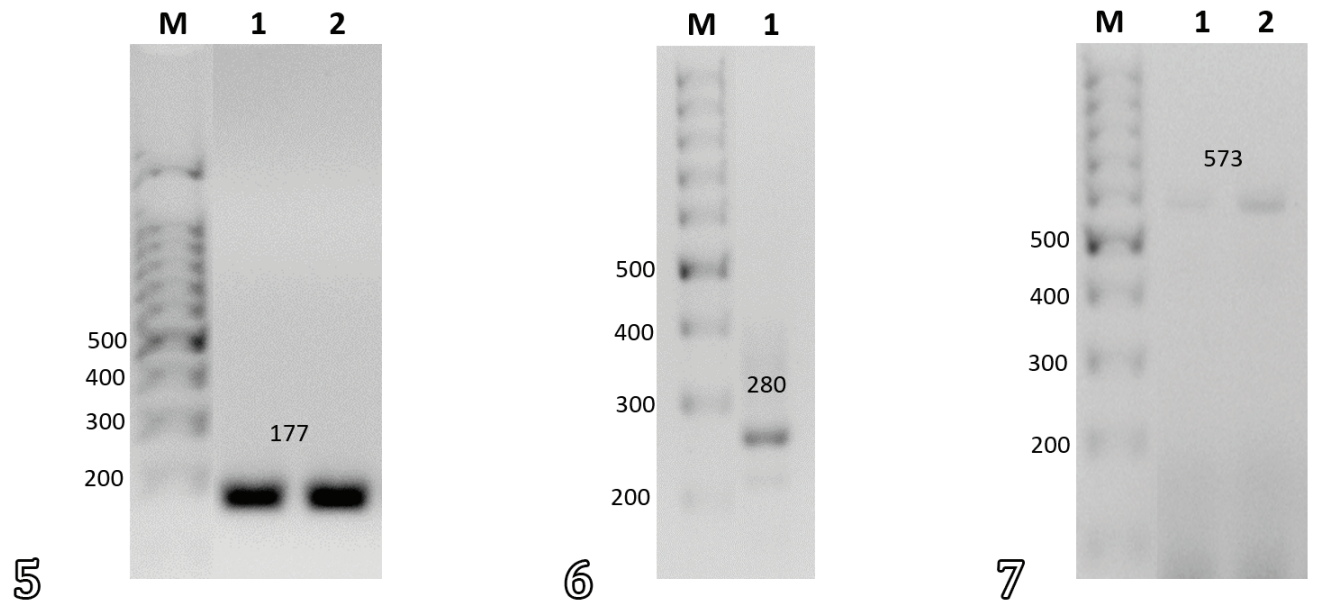

Fig.1-7. PCR products of the Stx1 and Stx2 subtypes genes in STEC isolates. (1) stx1a (478 pb) and stx1c (252 bp), (2) stx1d (203 bp), (3) stx2a (349 bp), (4) stx2b (251 bp), (5) stx2c (177 bp), (6) stx2d (280 bp) and (7) stx2g (573 bp).

Table 5. Antimicrobial resistance profile of Shiga-toxin Escherichia coli (STEC)

\begin{tabular}{|c|c|c|c|c|c|c|}
\hline \multicolumn{7}{|c|}{ Antimicrobial resistance profile of STEC (\%) } \\
\hline & \multicolumn{3}{|c|}{ Cattle $(n=59)$} & \multicolumn{3}{|c|}{ Sheep $(n=47)$} \\
\hline & Resistant & Sensitive & Intermediate & Resistant & Sensitive & Intermediate \\
\hline Ampicillin & 22 & 45.8 & 32.2 & 6.4 & 42.5 & 51.1 \\
\hline Cefazolin & 86.4 & 0 & 13.6 & 74.5 & 0 & 25.5 \\
\hline Cefoxitin & 6.8 & 81.3 & 11.9 & 8.5 & 78.7 & 12.8 \\
\hline Cefotaxime & 49.1 & 13.6 & 37.3 & 46.8 & 14.9 & 38.3 \\
\hline Cefepime & 18.6 & 8.5 & $72.9^{*}$ & 2.1 & 21.3 & $76.6^{*}$ \\
\hline Imipenem & 40.7 & 23.7 & 35.6 & 10.6 & 55.3 & 34 \\
\hline Ciprofloxacin & 6.8 & 62.7 & 30.5 & 6.4 & 68.1 & 25.5 \\
\hline Sulfazotrim & 8.5 & 91.5 & 0 & 0 & 95.7 & 4.3 \\
\hline Streptomycin & 27.1 & 11.9 & 61 & 25.5 & 12.8 & 61.7 \\
\hline Nitrofurantoin & 57.6 & 15.3 & 27.1 & 53.2 & 21.3 & 25.5 \\
\hline
\end{tabular}


Stx1d are commonly observed in other studies as well (Feng \& Reddy 2013, Jajarmi et al. 2017, 2018). Studies report that the subtypes Stx1a, Stx1c, and Stx1d have a low association with cases of HUS (Melton-Celsa 2014, Skinner et al. 2014).

In this study, the number of isolates positives for Stx1c gene in sheep was found to be 29.26\% (12/41) and 56.9\% associated with Stx1a, unlike the bovine samples, where it was as only found in association with $S t x 1 a$, with $63.16 \%$ (24/38). According to Feng \& Reddy (2013), Stx1c is generally associated with mild diarrhea and asymptomatic infections. It is the most common subtype among STEC strains isolated from sheep and their meat, which might justify the difference in its presence in bovine strains and sheep researched here. In other studies, with goats and calves, the subtype Stx1c was also reported to be most prevalent (Jajarmi et al. 2018, Taghadosi et al. 2018).

The subtype Stx2a+Stx2c was predominant in cattle, found in $63.16 \%(24 / 38)$ of the strains, while in sheep in $4.34 \%$ $(1 / 23)$ of the strains. Various virulence factors were found to be associated with different subtypes of Stx 2 in the study conducted by Franz et al. (2015). The Stx2a was positively associated with additional virulence factors, including eae, unlike Stx $2 b, S t x 2 d, S t x 2$ e, and Stx $2 g$, which showed a negative association with these factors. According to the same authors, the subtype $S t x 2 f$ is generally associated with milder disease, due to the general absence of $e h x A$ and $\operatorname{ter} B$ genes, both of which show a significant association with HUS.

The higher prevalence of $S t x 2 a$ is a health concern for the local population. Epidemiological data on human diseases indicate a stronger association of Stx2a strain with serious diseases, as compared to Stx1a alone. Moreover, intestine, epithelial, and endothelial cells are more sensitive to this subtype (Russo et al. 2014, Cherubin et al. 2019, Petro et al. 2019). Renal microvascular endothelial cells obtained from human glomeruli are about a thousand times more sensitive to Stx2a than to Stx1a (Melton-Celsa 2014).

In the present study, $15.15 \%$ (5/33) of STEC isolated from bovine feces had Stx $2 a, S t x 2 c$, and Stx2d simultaneously, a fact of major concern, since STEC producing these combinations are often related to HUS and hemorrhagic colitis in humans (Melton-Celsa 2014, Skinner et al. 2014).

In sheep, Stx $2 b$ was present in $73.91 \%(17 / 23)$ of the strains. However, $21.73 \%$ also harbored the $s t x 2 g$ subtype. Although $S t x 2 b$ and $S t x 2 d$ have reduced cytotoxicity to Vero cells, and $S t x 2 c$ toxin is more actively produced in these cells, Stx $2 d$ is just as toxic as $S t x 2 a$ when injected into animals. The subtype $S t x 2 b$ is associated with mild disease, and the subtypes $S t x 2 e, S t x 2 f$, and $S t x 2 g$ are closely associated with STEC infection in animals (Melton-Celsa 2014).

According to Franz et al. (2015), the Stx $2 b$ and Stx $2 d$ genes showed higher frequencies than the other genes. Our result was similar for the subtypes found in strains isolated from sheep feces. Although none of the strains had Stx2d,73.91\% $(17 / 23)$ had the Stx $2 b$ gene. Martins et al. (2015), also found that the subtype $S t x 2 b$ was the most common among sheep in Paraná, Brazil. Sheep farming is a very important animal activity in Brazil, and consequently, the risk of exposure to zoonotic pathogens is significant.

We meet higher frequency of MDR isolates, $67.8 \%$ in cattle, and $59.6 \%$ in sheep. Recent research shows high MDR-STEC rates, ranging from $66.4 \%$ (Gentle et al. 2020) to $45.45 \%$ (Yang et al. 2020). It is a known fact that these resistant bacteria can be easily transmitted from animals to humans via direct contact (Liu et al. 2016).

As per our results, $49.1 \%$ and $18.6 \%$ of the STEC strains obtained from cattle were resistant to cefotaxime and cefepime (third and fourth generation cephalosporins, respectively). In the isolates obtained from sheep, resistance to cefotaxime was not much different: $46.8 \%$. Likewise, almost $86.4 \%$ of bovine strains, and $74.5 \%$ of sheep strains, were resistant to cefazolin (first-generation cephalosporin). Probably, the exacerbated use of third and fourth-generation cephalosporins in animals is related to the selection of resistant bacteria in them (Yu et al. 2016, Yang et al. 2020).

Among the isolates analyzed, antibiotic resistance was observed for cefazolin, cefotaxime, nitrofurantoin, and imipenem. 57.6\% and 53.2\% of cattle and sheep STEC were resistant to nitrofurantoin. It is noteworthy that these molecules are routinely used in human medicine mainly nitrofurantoin and imipenem, important for the treatment of urinary tract infections and complicated infections. Therefore, the "Ministério da Agricultura, Pecuária e Abastecimento" (MAPA), Brazil, have banned the use of some antimicrobials in animal production following global trends. These data demonstrate the emergence of resistant isolates important for the human population among the food-producing animal population.

Resistance to nitrofurantoin is attributed to mutations in the genes that encode nitroreductase ( $n f_{S} A$ and $\left.n f S B\right)$ and also by plasmids that encode OqxAB efflux pumps. Studies have reported the emergence of nitrofurantoin-resistant Escherichia coli isolated from swine and poultry (Sørensen et al. 2003, Chen et al. 2012, Ho et al. 2016) due to the use of OLA, carbadox, mequind ox, and quinocetone antimicrobials, substrates of OqxAB. According to Chen et al. (2012) and Ho et al. (2016), these isolates are not commonly found in $E$. coli isolated from cattle. Therefore, the data from the present study point to the need for further research to understand the mechanisms of nitrofurantoin resistance in STEC isolated from cattle in Brazil.

According to Rabello et al. (2020), the six main classes of antimicrobials used in the clinic for cattle and sheep are penicillins, cephalosporins, macrolides, aminoglycosides, tetracyclines, and quinolones. And among those used in animal production are of the classes: beta-lactams, tetracyclines, macrolides, aminoglycosides, and sulfonamides.

It was also found that adult animals were eight times more likely to have STEC with greater pathogenic potential than young animals. The longer exposure time of adults and longer treatment time with antibiotics might justify this fact. This is a cause of concern because human exposure to adult animals and their products is usually greater as compared to young animals. The activities such as milking and slaughtering bring humans not only in direct contact with these reservoir animals, but also with products like contaminated milk, cheese, and meat. Also, it has been observed that pathogenic STEC strains are three times more multidrug-resistant. Therefore, in addition to being highly virulent strains for humans, they can be considered difficult to treat and eliminate, due to their high resistance to antimicrobials.

The results obtained in the present study, concerning the high resistance of STEC to antimicrobials in animals from several rural properties, may indicate indiscriminate 
use of antimicrobials in animals. According to Ibrahim et al. (2016), this contributes to the selection of strains that have antibiotic resistance genes and horizontal gene transfer between different species of bacteria.

\section{CONCLUSIONS}

Cattle and sheep, especially adults, are Shiga toxinproducing Escherichia coli (STEC) reservoirs with variants of high pathogenic potential and with a high rate of multidrug resistance to antimicrobials.

The antibiogram showed variations in the resistance profile of STEC, but the occurrence of multidrug-resistant STEC was consistent in cattle and sheep. The STEC of high pathogenic potential isolated from these animals had three times more chances of being multidrug-resistant to antimicrobials.

It is necessary to continue monitoring the susceptibility profile and evolution of resistance in microorganisms found in these animals, since they are considered sources of direct and indirect infection for humans.

Acknowledgments.- This study was financed in part by the "Coordenação de Aperfeiçoamento de Pessoal de Nível Superior" (CAPES), Brazil, Finance Code 001, "Conselho Nacional de Desenvolvimento Científico e Tecnológico" (CNPq), and "Fundação de Amparo à Pesquisa do Estado de Goiás" (FAPEG).

Statement of animal rights.- The authors did not work directly with the animals in this study. Therefore, the declaration of animal rights was not necessary.

Conflict of interest statement.- No conflict of interest of any kind is declared by the authors.

\section{REFERENCES}

Alonso C.A., Mora A., Díaz D., Blanco M., González-Barrio D., Ruiz-Fons F., Simónd C., Blanco J. \& Torres C. 2017. Occurrence and characterization of Stx and/or eae-positive Escherichia coli isolated from wildlife, including a typical EPEC strain from a wild boar. Vet. Microbiol. 207:69-73. <https://dx.doi.org/10.1016/j.vetmic.2017.05.028><PMid:28757042>

Chen X., Zhang W., Pan W., Yin J., Pan Z., Gao S. \& Jiao X. 2012. Prevalence of qnr, aac $\left(6^{\prime}\right)$-Ib-cr, qepA, and oqxAB in Escherichia coli isolates from humans, animals, and the environment. Antimicrob. Agents Chemother. 56(6):34233427. <https://dx.doi.org/10.1128/AAC.06191-11><PMid:22391545>

Cherubin P., Fildler D., Quiñoses B. \& Teter K. 2019. Bimodal response to Shiga toxin 2 subtypes results from relatively weak binding to the target cell. Infect. Immunol. 87(12):e00428-19. <https://dx.doi.org/10.1128/ IAI.00428-19><PMid:31527121>

CLSI 2018. M100 Performance Standars for Antimicrobial Susceptibility Testing. Clinical and Laboratory Standards Institute, Wayne, PA. Available at <https://clsi.org/media/1930/m100ed28_sample.pdf> Accessed on Mar. 12, 2019.

Feng P.C.H. \& Reddy S. 2013. Prevalences of Shiga toxin subtypes and selected other virulence factors among Shiga-Toxigenic Escherichia coli strains isolated from fresh produce. Appl. Environ. Microb. 79(22):6917-6923. <https://dx.doi.org/10.1128/AEM.02455-13><PMid:23995936>

Ferreira M.R.A., Freitas-Filho E.G., Pinto J.F.N., Dias M. \& Moreira C.N. 2014. Isolation, prevalence, and risk factors for infection by shiga toxin-producing Escherichia coli (STEC) in dairy cattle. Trop. Anim. Health Prod., Edinburgh, 46(4):635-639. <https://dx.doi.org/10.1007/s11250-014-0541-5> $<$ PMid:24510196>

Ferreira M.R.A., Silva T.S., Stella A.E., Conceição F.R., Reis E.F. \& Moreira C.N. 2015. Detection of virulence factors and antimicrobial resistance patterns in shiga toxin-producing Escherichia coli isolates from sheep. Pesq. Vet. Bras. 35(9):775-780.<https://dx.doi.org/10.1590/s0100-736x2015000900002>
Franz E., Van Hoek A.H.A.M., Wuite M., Van Der Wal F.J., De Boer A.G., Bouw E. \& Aarts H.J.M. 2015. Molecular hazard identification of non-0157 Shiga toxin-producing Escherichia coli (STEC). Plos One. 10(3):e0120353. <https://dx.doi.org/10.1371/journal.pone.0120353><PMid:25789994>

Gardiner B.J., Stewardson A.J., Abbott I.J. \& Peleg A.Y. 2019. Nitrofurantoin and fosfomycin for resistant urinary tract infections: old drugs for emerging problems. Aust. Prescr. 42(1):14-19 <https://dx.doi.org/10.18773/ austprescr.2019.002 > <PMid:30765904>

Gentle A., Day M.R., Hopkins K.L., Godbole G. \& Jenkins C. 2020. Antimicrobial resistance in Shiga toxin-producing Escherichia coli other than serotype 0157:H7 in England, 2014-2016. J. Med. Microbiol. 69(3):379-386. <https:// dx.doi.org/10.1099/jmm.0.001146> <PMid:32101158>

Ho P.-L., Ng K.-Y., Lo W.-U., Law P.Y., Lai E.L.-Y., Wang Y. \& Chow K.-H. 2016. Plasmid-mediated OqxAB is an important mechanism for nitrofurantoin resistance in Escherichia coli. Antimicrob. Agents Chemother. 60(1):537543. <https://dx.doi.org/10.1128/AAC.02156-15><PMid:26552976>

Ibrahim D.R., Dodd C.E.R., Stekel D.J., Ramsden S.J. \& Hobman J.L. 2016. Multidrug resistant, extended spectrum $\beta$-lactamase (ESBL) - producing Escherichia coli isolated from a dairy farm. FEMS Microbiol. Ecol. 92(4):fiw013. <https://dx.doi.org/10.1093/femsec/fiw013> <PMid:26850161>

Jajarmi M., Bodouei M.A., Fooladi A.A.I., Ghanbarpour R. \& Ahmadi A. 2018. Pathogenic potential of Shiga toxin producing Escherichia coli strains of caprine origin: virulence genes, Shiga toxin subtypes, phylogenetic background and clonal relatedness. BMC Vet. Res. 14(97):97. <https:// dx.doi.org/10.1186/s12917-018-1407-2><PMid:29548291>

Jajarmi M., Fooladi A.A.I., Badouei M.A. \& Ahmadi A. 2017. Virulence genes, Shiga toxin subtypes, major O-serogroups, and phylogenetic background of Shiga toxin-producing Escherichia coli strains isolated from cattle in Iran. Microb. Pathog. 109:274-279. <https://dx.doi.org/10.1016/j. micpath.2017.05.041><PMid:28578089>

Karmali M.A., Gannon V. \& Sargeant J.M. 2010. Verocytotoxinproducing Escherichia coli (VTEC). Vet. Microb. 140(3/4):360-370. <https://dx.doi. org/10.1016/j.vetmic.2009.04.011><PMid:19410388>

Liu Y.-Y., Wang Y., Walsh T.R., Yi L.-X., Zhang R., Spencer J., Doi Y., Tian G., Dong B., Huang X., Yu L.-F., Gu D., Ren H., Chen X., Lv L., He D., Zhou H., Liang Z., Liu J.-H. \& Shen J. 2016. Emergence of plasmid-mediated colistin resistance mechanism MCR-1 in animals and human beings in China: a microbiological and molecular biological study. Lancet Infect. Dis. 16(2):161-168. <https:// dx.doi.org/10.1016/S1473-3099(15)00424-7> <PMid:26603172>

Martins F.H., Guth B.E.C., Piazza R.M., Leão S.C., Ludovico A., Ludovico M.S., Dahbi G., Marzoa J., Mora A., Blanco J. \& Pelayo J.S. 2015. Diversity of Shiga toxin-producing Escherichia coli in sheep flocks of Paraná State, southern Brazil. Vet. Microbiol. 175(1):150-156. <https://dx.doi.org/10.1016/j. vetmic.2014.11.003><PMid:25465174>

Melton-Celsa A.R. 2014. Shiga Toxin (Stx) classification, structure, and function. Microbiol. Spectr. 2(4):1-13.<https://dx.doi.org/10.1128/microbiolspec. EHEC-0024-2013><PMid:25530917>

Petro C.D., Trojnar E., Sinclair J., Liu Z.-M., Smith M., O'brien A.D. \& Melton-Celsa A. 2019. Shiga toxin type 1a (Stx1a) reduces the toxicity of the more potent Stx2a in vivo and in vitro. Infect. Immunol. 87(4):e00787-18. <https:// dx.doi.org/10.1128/IAI.00787-18> <PMid:30670557>

Rabello R.F., Bonelli R.R., Penna B.A., Albuquerque J.P., Souza R.M., Cerqueira A.M.F. 2020. Antimicrobial resistance in farm animals in Brazil: an update overview. Animals, 10(4):552. <https://dx.doi.org/10.3390/ani10040552> $<$ PMid:32224900>

Russo L., Melton-Celsa A.R., Smith M.J. \& O’Brien A.D. 2014. Comparisons of native Shiga toxins (Stxs) type 1 and 2 with chimeric toxins indicate that the source of the binding subunit dictates degree of toxicity. Plos One. 9(3):e93463.<https://dx.doi.org/10.1371/journal.pone.0093463> <PMid:24671194>

Scheutz F., Teel L.D., Beutin L., Piérard D., Buvens G., Karch H., Mellmann A., Caprioli A., Tozzoli R., Marabito S., Strockbine NA., Melton-Celsa A., 
Sanchez M., Persson S. \& O’Brien A.D. 2012. Multicenter evaluation of a sequence-based protocol for subtyping Shiga Toxins and standardizing Stx nomenclature. J. Clin. Microbiol. 50(9):2951-2963. <https://dx.doi. org/10.1128/JCM.00860-12><PMid:22760050>

Shaheen B.W., Boothe D.M., Oyarzabal O.A. \& Smaha T. 2010. Antimicrobial resistance profiles and clonal relatedness of canine and feline Escherichia coli pathogens expressing multidrug resistance in the United States. J. Vet. Intern. Med. 24(1):323-330.<https://dx.doi.org/10.1111/j.1939-1676.2009.0468.x> $<$ PMid:20102505>

Skinner C., Patfield S., Stanker L.H., Fratamico P. \& He X. 2014. New high-affinity monoclonal antibodies against Shiga toxin 1 facilitate the detection of hybrid Stx1/Stx2 in vivo. Plos One 9(6):e99854. <https://dx.doi.org/10.1371/ journal.pone.0099854><PMid:24914553>

Sørensen A.H., Hansen L.H., Johannesen E. \& Sørensen S.J. 2003. Conjugative plasmid conferring resistance to olaquindox. Antimicrob. Agents Chemother. 47(2):798-799. <https://dx.doi.org/10.1128/AAC.47.2.798-799.2003> <PMid:2543696>

Taghadosi R., Shakibaie M.R., Alizade H., Hosseini-Nave H., Askari A. \& Ghanbarpour R. 2018. Serogroups, subtypes and virulence factors of Shiga toxin-producing Escherichia coli isolated from human, calves and goats in Kerman, Iran. Gastroenterol. Hepatol. Bed Bench. 11(1):60-67. <PMid:29564067>

Veneti L., Lange H., Brandal L., Danis K. \& Vold L. 2019. Mapping of control measures to prevent secondary transmission of STEC infections in Europe during 2016 and revision of the national guidelines in Norway. Epidemiol. Infect. 147:e267. <https://dx.doi.org/10.1017/S0950268819001614> $<$ PMid:31496450>

Yang G., Zhang S., Huang Y., Ye Q., Zhang J., Wu Q., Wang J., Chen M. \& Xue L. 2020. Isolation and characterization of non-o157 Shiga toxin-producing Escherichia coli in foods sold at retail markets in China. J. Food Protect. 83(3):460-466. <https://dx.doi.org/10.4315/0362-028X.JFP-19-025> $<$ PMid:32065650>

Yang R., Abraham S., Gardner G.E., Ryan U. \& Jacobson C. 2017. Prevalence and pathogen load of Campylobacter spp., Salmonella enterica and Escherichia coli 0157/0145serogroup in sheep faeces collected at sale yards and in abattoir effluent in Western Australia. Aust. Vet. J. 95(5):143-148. <https:// dx.doi.org/10.1111/avj.12572> <PMid:28444752>

Yu X., Tang X., Zuo J., Zhang M., Chen L. \& Li Z. 2016. Distribution and persistence of cephalosporins in cephalosporin producing wastewater using SPE and UPLC-MS/MS method. Sci. Total Environ. 569-570:23-30. <https://dx.doi. org/10.1016/j.scitotenv.2016.06.113><PMid:27328396> 